\title{
Strategi Peningkatan Penjualan Produk UMKM Kerupuk Rambak RW 15 Kelurahan Rejosari
}

\author{
Arum Jayati ${ }^{1}$, Chintya Siska Febrina ${ }^{2}$, Ibnu Hasan Ashari ${ }^{3}$, Dwita Razkia ${ }^{4}$ \\ ${ }^{12}$ Fakultas Ekonomi dan Bisnis, Universitas Muhammadiyah Riau \\ ${ }^{3}$ Fakultas Hukum, Universitas Muhammadiyah Riau \\ ${ }^{4}$ Fakultas Studi Islam, Universitas Muhammadiayah Riau \\ email : 180301127@student.umri.ac.id
}

\begin{abstract}
In the Community Service Program group 13 conducted research on Small and Medium Enterprises (UMKM) of Rambak Crackers located in Pekanbaru City, RW 15, Rejosari Village, Tenayan Raya District. This KKN activity is carried out using a descriptive method with information on internal and external factors on competitive advantage in the form of raw materials, cash books, machines and tools, work methods / technology, packaging, promotions and marketing. Production activities are relatively simple in terms of marketing. Products are packaged using plastic packaging and have not used the sales logo. During the KKN activity, we as group 13 KKN students provided counseling and assistance for the business. Hopefully this activity can provide benefits for partners in developing their business.
\end{abstract}

Keywords: UMKM, Kerupuk Rambak, Marketing, Cash Book, Packaging

\begin{abstract}
Abstrak
Dalam kegiatan Kuliah Kerja Nyata (KKN) kelompok 13 melakukan penelitian terhadap Usaha Kecil dan Menengah (UMKM) Kerupuk Rambak terdapat di Kota Pekanbaru, RW 15, Kelurahan Rejosari, Kecamatan Tenayan Raya bertujuan untuk menyusun strategi peningkatan penjualan dan pengembangan usaha agar semakin meningkat kedepannya. Kegiatan KKN ini dilakukan dengan menggunakan metode deskriptif disertai informasi faktor internal dan eksternal pada keunggulan kompetitif berupa bahan baku, buku kas, mesin dan alat, metode kerja / teknologi, kemasan, promosi dan pemasaran. Kegiatan produksi dilakukan tergolong sederhana dari segi pemasarannya. Produk dikemas menggunakan kemasan plastic dan belum menggunakan logo penjualan. Selama kegiatan KKN berlangsung, kami sebagai mahasiswa KKN kelompok 13 memberikan penyuluhan dan pendampingan usaha tersebut. Kegiatan ini semoga dapat memberikan manfaat bagi mitra dalam mengembangkan usahanya.
\end{abstract}

Kata Kunci: UMKM, Kerupuk Rambak, Pemasaran, Buku Kas, Kemasan

\section{PENDAHULUAN}

\section{A. Latar Belakang}

Ekonomi merupakan salah satu komponen utama yang paling penting bagi negara atau daerah dalam menunjang kehidupan masyarakat. Usaha Mikro Kecil dan Menengah (UMKM) merupakan usaha yang dapat membantu menunjang perekonomian di
Indonesia dalam jumlah dan kemampuannya dalam menyerap tenaga kerja, manajemen yang sederhana, modal yang terbatas bagi masyarakat. Hal itulah salah satu alasan kelompok 13 melakukan kegiatan KKN dengan tema "Desa Tangguh Ekonomi" berupa UMKM yang terdapat di Kelurahan Rejosari. 
Kelurahan Rejosari terletak di Kecamatan Tenayan Raya, Kota Pekanbaru, Provinsi Riau. Jarak antara Kelurahan Rejosari dan pusat Kota Pekanbaru yaitu sekitar 6,9 Kilometer. Sebagian besar penduduk di Kelurahan Rejosari memiliki profesi di bidang perdagangan dan jasa sekitar 44,34\% yang dijumpai di masyarakat memiliki UMKM bagi produk yang dijual. Salah satu UMKM yang terdapat di Kelurahan Rejosari adalah Kerupuk Rambak. Usaha kerupuk rambak memiliki potensi yang cukup besar di bagian pemasaran, tetapi kurangnya promosi serta pemasaran yang belum luas sehingga usaha tersebut kurang berkembang.

Selain itu, kami mahasiswa KKN membantu mitra untuk melakukan pembaharuan pada strategi pemasarannya dengan meningkatkan sistem promosi dan menambahkan logo pada kemasan kerupuk rambak. Kemasan produk merupakan unsur penting dalam mempengaruhi konsumen dan banyaknya penjualan pada produk UMKM. Tujuan kegiatan KKN ini adalah untuk mengetahui strategi yang tepat dalam meningkatkan penjualan produk kerupuk rambak RW 15 Kelurahan Rejosari.

\section{B. Rumusan Masalah}

Dari latar belakang pada strategi peningkatan penjualan munculah rumusan masalah yang penulis temukan pada mitra pada saat melakukan kegiatan KKN, yaitu:

1) Bagaimana cara meningkatkan penjualan produk UMKM kerupuk rambak yang ada di RW 15 Kelurahan Rejosari?

2) Bagaimana strategi dalam meningkatkan penjualan produk UMKM kerupuk rambak yang ada di RW 15 Kelurahan Rejosari?

\section{Landasan Teori \\ 1. Promosi dan Pemasaran}

Promosi (promotion) adalah "usaha atau upaya untuk memajukan atau meningkatkan; misalnya untuk meningkatkan perdagangan atau memajukan bidang usaha." (Rivai Wirasasmita, dkk, 2002:39) Promosi adalah arus informasi atau persuasi satu-arah yang dibuat untuk mengarahkan seseorang atau organisasi kepada tindakan yang menciptakan pertukaran dalam pemasaran." (Basu Swastha, 2007 : 222

Pemasaran dalam arti sempit oleh para pengusaha diartikan "sebagai pendistribusian, termasuk kegiatan yang dibutuhkan untuk menempatkan produk yang berwujud pada tenaga konsumen rumah tangga dan pemakai industri”. (M. Mursid, 2014 : 217). Artinya adalah bahwa pemasaran merupakan suatu kegiatan yang di mana bertujuan untuk memasarkan atau mendistribusikan suatu produk yang dimiliki ke suatu tempat untuk dijual.

\section{Produk}

Produk adalah upaya mengembangkan produk atau pasar yang baru dalam pertumbuhan, peningkatan penjualan, produktivitas, stabilitas, dan profitabilitas yang berkaitan untuk pemasaran atau teknologi dengan produk yang sudah ada (F. R. David, 2006).

\section{Persamaan Dasar Akuntansi}

Persamaan dasar akuntansi merupakan unsur mendasar dalam akuntansi dari pencatatan, pembuatan, pencatatan awal mengenai transaksi penjualan dalam pembuatan akun dalam akuntansi (Nur Khabibah \& Agus Wahyudin (2020) Persamaan dasar akuntansi dianggap mendasar dalam pembuatan buku kas yang mengandung akun-akun masuk dalam penjualan. 


\section{METODE PENGABDIAN}

Penelitian kegiatan KKN kelompok 13 menggunakan metode penelitian kualitatif untuk melihat kondisi penjualan mengenai strategi pemasaran melalui deskripsi dalam kata-kata dan bahasa. Objek penelitian adalah UMKM Kerupuk Rambak di RW 15 Kelurahan Rejosari, Kecamatan Tenayan Raya, Pekanbaru. Alasan memilih objek penelitian karena ingin melihat bagaimana perkembangan UMKM di sekitar kelurahan Rejosari meningkatkan penjualan di Pekanbaru. Sumber data yang digunakan adalah data primer adalah sumber data yang digunakan dalam memberikan data kepada mitra yang diperoleh langsung dengan melakukan observasi, wawancara, sesuai dengan keadaan penelitian.

\section{HASIL DAN PEMBAHASAN}

Berikut ini adalah hasil yang telah dicapai dari pelaksanaan KKN sesuai dengan program yang sudah kami jalankan yaitu :

\section{A. Pembuatan Desain Logo Produk}

Pada kegiatan ini kami berhasil membuat sebuah logo baru untuk UMKM Kerupuk Rambak dengan tujuan agar dapat menarik minat pelanggan sehingga dapat terjual banyak di pasaran. Dalam hal ini kami membuat serta mencetak logonya untuk membantu mitra. Setelah itu logonya akan kami berikan kepada mitra agar dilanjutkan kedepannya. Di mana sebelumnya kami juga sudah melakukan penyuluhan atau sosialisasi mengenai logo yang dibuat.Jika dilanjutkan oleh mitra potensinya sangat bagus sehingga dapat menjadi ciri khas dari produk tersebut.

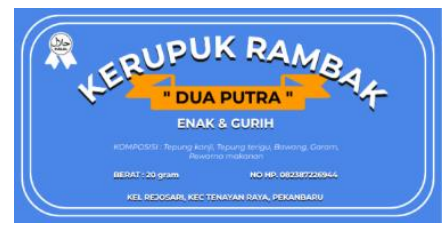

Gambar 1. Desain logo untuk produk kerupuk rambak

\section{B. Pengembangan Kemasan Produk UMKM Kerupuk Rambak}

Pada kegiatan ini kami melakukan pengembangan kemasan untuk produk UMKM Kerupuk Rambak. Salah satu cara untuk mengembangkannya dengan cara kami membantu memberikan sebuah alat press plastik yang berguna untuk menyegel produk kerupuk. Berdasarkan hasil penelitian yang telah kami capai bahwa kemasan produk kerupuk rambak berkembang menjadi lebih baik dengan alat tersebut. Kegiatan ini memiliki potensi keberlanjutan kedepannya di mana mitra dapat bekerja dengan cepat dan maksimal dalam, mengemas produk kerupuk tersebut.

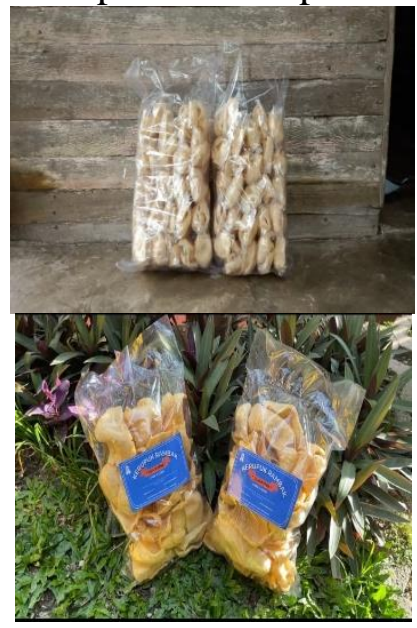

Gambar 2. Kemasan produk sebelum ada logo (atas), kemasan produk

sesudah ada logo (bawah)

\section{Pembuatan Buku Kas Manual}

Pada kegiatan ini kami membantu mitra membuat buku kas manual untuk mitra yaitu Ibu Suwati yang memiliki UMKM Kerupuk Rambak.Tujuannya adalah untuk mengetahui menghitung arus kas masuk dan keluar serta perhitungan biaya produksi. Di mana pada minggu pertama kami melakukan 
sosialisasi mengenai cara membuat buku kas manual kepada Ibu Suwati sebagai mitra.

Hasil yang telah kami capai adalah pembuatan buku kas manual yang dilakukan dari minggu kedua hingga minggu keempat. Hasilnya adalah terhitungnya arus kas masuk dan keluar yang ada di mitra UMKM Kerupuk Rambak tersebut.

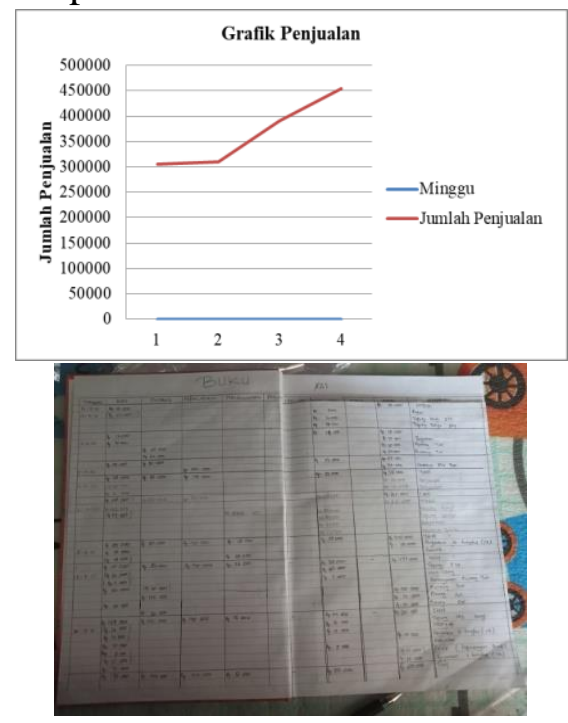

Gambar 3. Grafik penjualan

kerupuk rambak selama 1 bulan (atas), gambar buku kas manual untuk mitra (bawah)

Berdasarkan dari gambar grafik di atas, terlihat ada kenaikan penjualan produk kerupuk rambak dari setiap minggunya selama satu bulan. Artinya program yang dijalankan berhasil sehingga dapat memberikan dampak signifikan terhadap penjualan produk yang meningkat.

\section{Pembuatan dan Pengurusan Surat}

\section{Izin BPOM (Badan Pengawas} Obat dan Makanan)

Pada kegiatan ini kami mencoba untuk mengurus perizinan BPOM di kantor Badan Pengawas Obat dan Makanan Kota Pekanbaru. Namun mengalami kendala dikarenakan BPOM tidak bisa melakukan pemeriksaan terhadap sampel makanan kerupuk rambak yang dibuat oleh mitra yaitu Ibu Suwati. Hal ini membuat pengurusan surat izin BPOM untuk mitra menjadi terkendala sehingga tidak bisa dilaksanakan.

\section{E. Pengembangan Sistem Promosi} dan Pemasaran Kerupuk Rambak

Pada kegiatan ini kami mencoba memperbarui sistem pemasaran produk UMKM Kerupuk Rambak agar dikenal oleh masyarakat sekitar. Kami memperbaharui promosi dengan menggunakan media sosial seperti Whatsapp dan Facebook. Selain itu, dalam tahap jalur distribusi kami juga melakukan pemasaran melalui kedai-kedai serta rumah makan atau tempat makan lainnya yang sesuai untuk memasarkan produk Kerupuk Rambak sehingga dan berguna bagi mitra untuk meningkatkan penjualan produk dan menambah pemasukan.

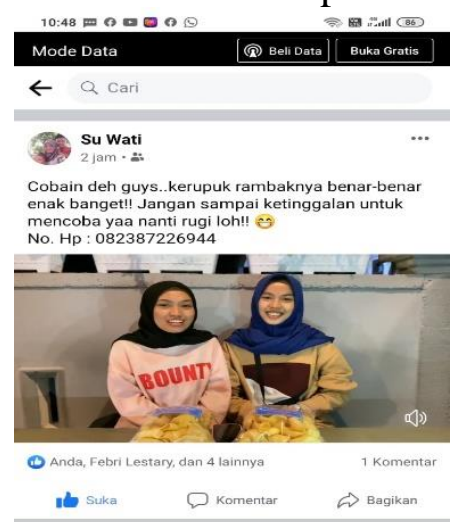

Gambar 4. Promosi melalui media sosial yaitu facebook

Seperti pada gambar di atas, kami juga membuat sebuah video untuk promosi produk kerupuk rambak yang di upload ke facebook mitra. Video promosi tersebut bertujuan untuk membantu mitra UMKM Kerupuk Rambak promosi agar pemasarannya bisa jauh berkembang.

\section{F. Perancangan Jalur Distribusi}


Pada tahap ini kami berhasil membuat jalur distribusi untuk mitra UMKM Kerupuk Rambak. Di mana jalur distribusi yang didapat adalah diarahkan ke toko-toko yang menjual makanan, kemudian ke rumah makan atau tempat makan yang lain yang memang sesuai dan cocok untuk memasarkan produk kerupuk rambak tersebut.

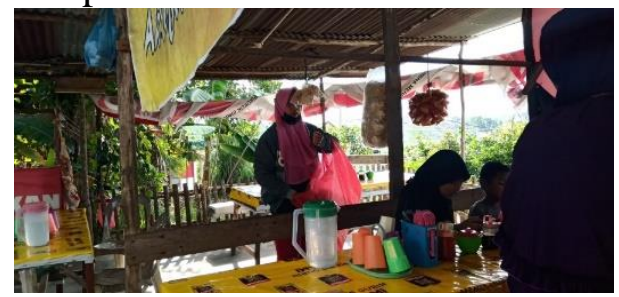

Gambar 5. Kegiatan pendistribusian kerupuk rambak

Dengan adanya jalur distribusi ini, membuat mitra menjadi lebih mudah dalam memasarkan produknya. Ditambah dengan adanya logo pada kemasan produk akan menjadi lebih mudah bagi konsumen untuk mengenali kerupuk rambak. Sehingga potensi keberlanjutan sangat bagus untuk meningkatkan penjualan produk kerupuk rambak sesuai dengan program yang kami jalankan.

\section{SIMPULAN}

\begin{tabular}{rrrr}
\multicolumn{2}{c}{ Berdasarkan program } & kerja \\
kegiatan KKN mahasiswa UMRI
\end{tabular} Kelompok 13 A Tenayan Raya berjalan lancar. Beberapa hasil yang telah dicapai dalam UMKM kerupuk rambak adalah pembuatan logo merek, kemasan, pembuatan buku kas manual untuk mitra agar mengetahui berapa setiap hari arus kas masuk dan keluar. Dalam segi pemasaran telah tercapai melalui media sosial seperti Whatsapp dan Facebook, dan dalam jalur distribusinya berupa rumah makan, kedai-kedai, dan lain sebagianya.

\section{UCAPAN TERIMAKASIH}

Kami sebagai mahasiswa KKN Kelompok 13 reg A, mengucapkan terima kasih kepada mitra UMKM Kerupuk Rambak
Ibu Suwati yang telah bersedia bekerja sama dengan kami sebagai mitra KKN.

\section{DAFTAR PUSTAKA}

[1] Mursid, M. 2014. Manajemen Pemasaran. PT. Bumi Aksara : Jakarta.

[2] Swastha, Basu. 2007. Pengantar Bisnis Modern. Edisi ketiga Cet ke 1. Liberty Yogyakarta : Yogyakarta.

[3] Wirasasmita, Rivai, dkk. 2002. Kamus Lengkap Ekonomi. Pionir Jaya : Bandung. 